\title{
Fundamentals of Sustainable Business
}

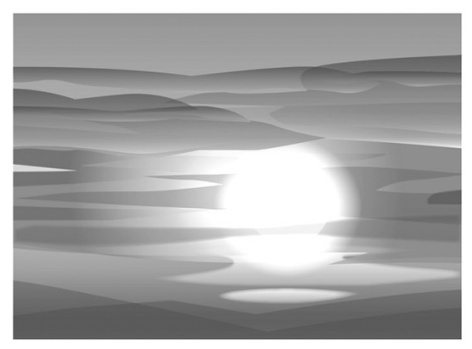

A Guide for the Next 100 Years 


\section{World Scientific Series on 21st Century Business}

ISSN: 1793-5660

Vol. 1 New Business in India: The 21st Century Opportunity by Paul Davies

Vol. 2 Indian Economic Superpower: Fiction or Future edited by Jayashankar M. Swaminathan

Vol. 3 China Rising: Will the West be able to Cope? The Real Long-Term Challenge of the Rise of China - and Asia in General by Jan Willem Blankert

Vol. 4 Fundamentals of Sustainable Business: A Guide for the Next 100 Years by Matthew W. Tueth 


\section{Fundamentals of Sustainable Business}

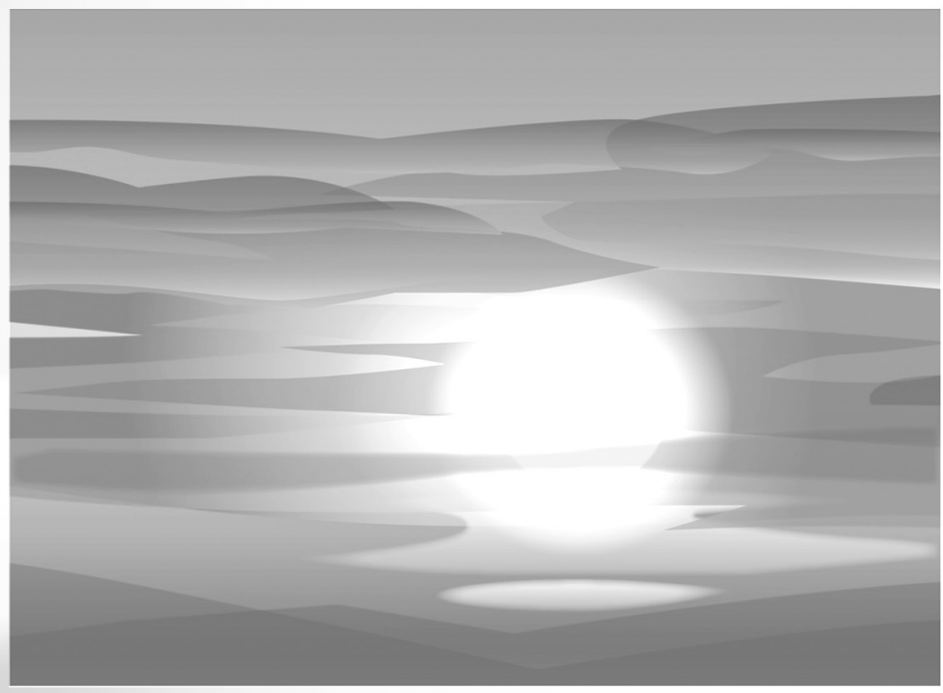

\section{A Guide for the Next 100 Years}

\section{Matthew Tueth}

Aquinas College, USA

\section{WF world Scientific}


Published by

World Scientific Publishing Co. Pte. Ltd.

5 Toh Tuck Link, Singapore 596224

USA office: 27 Warren Street, Suite 401-402, Hackensack, NJ 07601

UK office: 57 Shelton Street, Covent Garden, London WC2H 9HE

\section{British Library Cataloguing-in-Publication Data}

A catalogue record for this book is available from the British Library.

\section{World Scientific Series on 21st Century Business - Vol. 4 FUNDAMENTALS OF SUSTAINABLE BUSINESS A Guide for the Next 100 Years}

Copyright $@ 2010$ by World Scientific Publishing Co. Pte. Ltd.

All rights reserved. This book, or parts thereof, may not be reproduced in any form or by any means, electronic or mechanical, including photocopying, recording or any information storage and retrieval system now known or to be invented, without written permission from the Publisher.

For photocopying of material in this volume, please pay a copying fee through the Copyright Clearance Center, Inc., 222 Rosewood Drive, Danvers, MA 01923, USA. In this case permission to photocopy is not required from the publisher.

ISBN-13 978-981-283-932-9

ISBN-10 981-283-932-1

Typeset by Stallion Press

Email: enquiries@stallionpress.com

Printed in Singapore. 
This book is dedicated to the natural world that continues to support, inspire, and teach us and to the many people who recognize its splendor. 
This page intentionally left blank 


\section{Preface}

Fundamentals of Sustainable Business was written for students, business persons, and all others who are curious about the topic of sustainable business and are looking for a clear, thorough, and intriguing overview of this movement. Although previous books discuss certain aspects of sustainability, Fundamentals of Sustainable Business provides a comprehensive outline of the often misunderstood and over-simplified topic of sustainable business. This book offers considerable insight into the relatively new and compelling approach to human enterprise. Whether you are an ardent environmentalist, an ultra-conservative business owner, or somewhere in between, this book challenges a number of common and fundamental beliefs about the relationship between the natural world and human endeavor. It does not merely suggest an adjustment of conventional business assumptions or environmental theory, but rather outlines a radical departure from these traditional and seemingly disparate ideologies and proffers a unified and congruent body of thought. This book considers the problems of business, not simply the problems in business.

We will depart from traditional environmental and business perspectives so that you may consider some of the biggest challenges facing humankind from a different, and perhaps unfamiliar, perspective. The extensive economic, environmental, and social problems brought on by the first industrial revolution that have intensified over time are briefly reviewed but are not discussed in great detail in this text. Other books by contemporary authors such as Paul Hawken, Amory and Hunter Lovins, and William McDonough have previously documented this increasingly troubling predicament. Rather, this book concentrates on describing a shift from our current path of undermining vital support systems to a legacy of long-term opportunity and 
prosperity. People from a wide variety of experiences, perspectives, and places have already begun to embrace this extraordinary movement, and hopefully, an even more diverse fabric of society will continue to discover its relevance and value.

Let us turn our attention to our own lives for a moment to examine the movement's relevance to that situation. Most adults work long and hard in a variety of ways to earn a living and to perhaps even support a family. Although many of us enjoy our chosen professions, nearly all of us look forward to our free time spent in a variety of pleasurable activities. Family and friends may be high on such a list of activities, along with travel, the theater, music, books, movies, sporting events, exercise, camping, and even service to church or community. Our education, life experiences, and personal likes and dislikes all influence the free-time activities we select. Even though the amount of leisure time inside many developed nations has been shrinking for the past several decades, our free-time pursuits remain very important to us and to the quality of our lives. ${ }^{1}$

Our material belongings also influence the quality of our lives because they enable us to reside comfortably in our homes, travel to distant places, communicate with others, and enjoy a relatively comfortable life. Most readers of this book likely have a large inventory of possessions including vehicles, furniture, appliances, electronic devices, clothes, and recreational equipment. We have access to nearly unlimited retail product and service options, for example, a regional mall for clothing, a super-store for electronics, and grocery stores or restaurants for food. We have come to expect fully stocked store shelves and easily accessed e-businesses offering endless products via the Internet. Products at these outlets appear limitless, and only our cash supply or credit availability seems to restrict our purchases.

Spiritual considerations aside, what provides your material possessions and makes your enjoyable free-time activities possible? A common answer to this question might be simply the business sector. The worldwide industrial infrastructure extracts, processes, manufactures,

\footnotetext{
${ }^{1}$ See Jacobs and Gerson (2001) for an elaboration of these trends.
} 
and markets the goods and services that global consumers desire. But a closer look at this question begs further consideration: what actually supplies the raw materials and energy that must feed the myriad of industrial processes? Consider that whether you live in Bangkok, Thailand, or Bar Harbor, Maine, every human endeavor, project, and activity is made possible directly by the natural world. Whether you enjoy rap music, classical music, walks on the beach, walks down Fifth Avenue, gourmet meals, Big Macs, television, cell phones, the company of family and friends, or simply relaxing and breathing - the natural world continually provides all the essential materials and energy for life on Earth. For example, green plants are the only entity on Earth that captures incoming solar energy and stores it in the chemical bonds of simple sugars; through this process, they release oxygen, a vital component of the air. In short, the entire animal kingdom, including man, entirely depends upon green plants for food to eat and oxygen to breathe. No other source for these two vital commodities exists. Green plants also help to maintain global and local climates, make habitat available for wildlife, build soil fertility and reduce erosion, muffle urban noise, offer shade and wind protection, provide the basis for many dozens of medicines, and generally beautify the planet.

Today most of us go about our lives breathing, drinking, eating, working, and recreating, all the while taking for granted the abundant oxygen, clean water, beauty, and food available to us. Americans typically are not aware at a conscious level of our dependence upon the natural world for the things we need and the things we enjoy most in our daily lives. The combination of the prodigious retail and marketing sectors and the lack of understanding of environmental principles in all levels of education also contribute substantially toward a developed world culture largely ignorant of the vital role of the natural world in our everyday lives. Not surprisingly, this constantly reinforced environmental disconnect translates into a general apathy for the natural world. Another commonly held supposition is that the natural world has an unlimited capacity to continue to provide us with everything we need and want and to absorb the various types and levels of industrial assaults and pollution. 
Some of us may also be surprised to learn that the way our industrial systems meet our physical needs also unnecessarily depletes resources, puts persistent toxins into the biosphere, and results in global climate change, thereby decreasing options for future generations of world residents. The lack of recognition of the link between human prosperity and a healthy natural world has fostered an industrial system that still provides the goods and services we want in the immediate future but also brings momentous long-term negative consequences for all life on Earth. After briefly framing this unfortunate reality in Chapter 1, Fundamentals of Sustainable Business then concentrates on a new approach of solution-oriented systemic innovations that have begun to solve these dilemmas and offer rational hope for an abundant and healthy future.

Let's now turn our attention to the situation of personal transportation in the U.S. Gasoline today costs approximately eight times what it did just 35 years ago and, even when adjusted for inflation, a substantial price increase influences the transportation habits of many middle- and lower-class Americans. Had the automobile industry originally chosen a perpetually abundant and clean source of energy such as sunlight and then continuously improved a technology to support this selection, both the price and cost (they are in fact quite different) of personal transportation would be far less today, as would the climate-warming emissions from humanity's massive vehicle fleet.

But rising energy prices, tailpipe pollution, and a changing global climate are not the only undesirable results of our transportation technology of choice. We consistently use materials for the interior of our vehicles that release volatile toxins during the first year of ownership (yes, that new car smell) and subject riders to chronic inhalation of harmful contaminates. Owners of new cars are mostly unaware of this insidious assault on their bodies, or if aware, they may simply accept these conditions and consider these harmful effects as an unavoidable price of affluence. We also find that similar tragic consequences accompany numerous other products we use, from hospital intravenous (IV) tubes to carpeting to baby toys. Most of these isolated toxic exposures do not cause serious health problems alone, 
but the combined effects from dozens of minor (and completely unnecessary as we will see) day-to-day exposures pose significant threats to human health.

The following chapters present a truly revolutionary approach to business that has the capacity to concurrently produce long-term profitable businesses and local jobs, build healthy and vibrant communities, and enhance the natural world. We will examine a new paradigm for communities and organizations that a growing group of innovative business leaders around the world have already begun to embrace and implement. We will discuss the work of a number of visionary commercial pioneers that have set the tumblers in motion for this next industrial revolution. In the development of this new strategy, we will study an energy and materials system that has over 3.85 billion years of unprecedented success. We will learn how to build lasting value and wealth for ourselves, for future generations, and for all other species henceforth by our everyday actions at home, at work, and even during our leisure time.

Does this optimistic scenario sound too good to be true? This movement has already begun in many places around the world and has become, among other things, a considerable advantage for involved businesses and communities. This book summarizes the most salient work of leading visionaries in the sustainable business movement and introduces some original concepts as well. I ask that you read the following chapters with an open mind, allowing your imagination free reign. I encourage you to prepare to challenge and reshape a number of your basic beliefs and trust your intuition rather than rely on your past practices throughout the process. Realize that remodeling a personal paradigm is often uncomfortable, but at the same time such a conversion can be immensely rewarding. Expect your perspective of modern life to change during and after reading this solution-oriented text, and expect to find the experience startling, logical, and captivating. Most importantly, do not be surprised to find yourself drawn toward a more satisfying and engaging relationship with your community, the natural world, and business, which may inspire new personal contributions from you that will aid in the transformation of humans into a positive force on our planet for all time. 
The following is a preview of what we can expect as we move through Fundamentals of Sustainable Business: First, an initial short summary of the adverse effects of commerce since the first industrial revolution is presented. Several serious flaws of conventional business are briefly discussed as well as problems in the natural world and our own communities that were brought on by these failings. We examine the subsequent emergence of a movement from inside business that has begun to direct organizations to more effective and positive activities. As we will see, this new approach gives us a framework to simultaneously advance business, the natural world, and human communities.

Both our energy and material processes are thoroughly discussed and reconsidered. We reflect on the most intelligent source for help with the key changes inside business and why this consultant holds such promise for humankind. Stories of cutting-edge businesses of all sizes, types, and locations in the sustainable business movement are featured along with metrics to measure success. We consider the appropriate roles of specific business positions as well as the function of higher education and of government in this movement. In the face of current globalization trends, we examine the possible evolution of regional communities into healthy, diverse, abundant, self-sufficient, and beautiful places for countless generations to grow and prosper. Finally, obstacles to this transformation and the lurking pitfalls that could impede its progress are explained and considered.

I congratulate you on your decision to explore the ideas contained in these chapters. Students of all ages who consider the themes found in Fundamentals of Sustainable Business react in a variety of ways to the experience. As an educator in this regard, I have known many people who have described the experience as an epiphany business people who now thrive by putting these principles into practice, consumers who contribute by reassessing and redirecting what they buy and whom they patronize, and college students who follow their new passion in the preparation for their professional careers. Many of these engaged citizens choose to lobby their political leaders to work for positive changes in policy directives.

At the same time, some seasoned business folk find it difficult to accept these ideas in their entirety, owing in part perhaps to their 
reluctance to acknowledge personal complicity in the insidious tragedies of business as usual. Others lack the familiarity and understanding of the natural world and how our industrial activities systematically degrade the planet. Still other experienced adults accept and internalize the tenets of this movement and very quickly become impassioned supporters. But no matter which perspective you bring to the table, this book will provide a compelling and stimulating journey through a variety of dilemmas and solutions that offer previously unimagined outcomes for business, the natural world, and human communities. The extent to which this reading experience produces a change in perspective and generates action is personal and dynamic. Some readers may find that they intuit huge implications and changes generated by this body of thought gradually. In fact, if you read this book a second time, the principles outlined herein may resonate even deeper with you and provide an even more enjoyable and rewarding experience.

Your background and life experiences no doubt helped to motivate your curiosity in this movement; actually, the foundation of my involvement with sustainable business is also rooted in the distant past. I grew up in the 1950s and 60s in the industrial town of Alton, Illinois located on the banks of the Mississippi River just north of St. Louis, Missouri. My mother's standing rules were that her boys (my two older brothers and I) play outside every summer day (unless it was raining) and walk over a mile across town to and from our grade school and high school. Because of her edicts, I regularly landed in Alton's many parks and woods and at the river's edge.

One bright summer day I was climbing up and over a variety of dead tree snags along the banks of Old Man River when I noticed a curious tan rock about the size of one of my mom's chocolate chip cookies half buried in the riverbank sand. After extracting and washing off my prize, I noticed two curious markings on one side of the rock. Unable to interpret their meanings, I ran about five minutes back into town to Haynor Public Library. I carried my find into the geology section and in about 45 minutes, to my amazement, I found an illustration of a nearly identical rock in a book of fossils. The text confirmed it as a fossil of a freshwater fish. I returned home later that afternoon and carefully wrapped this treasure in one of my father's old 
rags and placed it gently among my other priceless finds of petrified wood, broken arrowheads, and various other unidentified rock specimens for later examination in my childhood leisure. This attentioncommanding experience was fairly typical of a long line of magically satisfying everyday events that the outdoors continued to provide in my youth. Clearly, nature was a fountainhead of wonders and mysteries for this ordinary Midwestern boy.

After graduating from high school in 1971, keenly aware of my affinity for the outdoors, I earned a bachelor's degree in wildlife management from Southern Illinois University at Carbondale. I spent the better part of 1977 working near Mt. St. Helens for the U.S. Forest Service in the Gifford Pinchot National Forest of Washington State; I missed the violent 1980 volcanic eruption by only a few geological seconds. In my next 20 professional years, I worked in the outdoors again, this time employed by the Illinois Department of Natural Resources.

Firmly ensconced inside the State of Illinois workforce and heading for full retirement in 2013, I was drawn to pursue a master's degree in environmental studies at the Edwardsville campus of Southern Illinois University. A graduate degree in my lifelong passion would hopefully fill in the gaps left by my casual but consistent efforts to improve my understanding of the natural world and how humans relate to it. After completing two years of evening classes and a thesis that concentrated on contemporary sustainability issues, I graduated in May 1997.

Seizing on the opportunity to maintain academic momentum and commit professional suicide, I resigned my enjoyable and reasonably lucrative position with the State of Illinois and intrepidly began the pursuit of a Ph.D. in environmental science at Oklahoma State University in Stillwater. With my deep curiosity about man's relationship to the natural world and a newfound passion to teach, I spent the next three years enrolled in doctoral courses, teaching undergraduate courses, and working diligently on my dissertation research project. I successfully passed my comprehensive exams and defended my dissertation research, which dealt with sustainability factors in ancient civilizations, and graduated in May 2000. 
I accepted an assistant professor position at the beautifully wooded campus of Aquinas College in Grand Rapids, Michigan and began my life as a tenure-track professor in August 2000. Just as I was firmly committed to teaching environmental studies and geography, another life-changing opportunity appeared. The Aquinas provost (a former history professor and the current president of the college) called a meeting with the business and science faculty in the fall of 2002 and asked if anyone had an interest in developing a new academic concentration involving environmental studies, science, and business. Looking around the room, the provost saw that no hands were raised, except for the new environmental studies professor in the back row. The provost thanked everyone for attending and promptly dismissed the meeting.

Thankfully, no one in the room noticed that I was dumbstruck. I remember the situation as surreal; had I misheard or misinterpreted what had just happened? - The subject had just been raised to develop an interdisciplinary program involving business and environmental science! Throughout my undergraduate and graduate academic careers I had always believed that the theme of higher education to emphasize single-discipline learning was not in the best interest of life on Earth (my undergraduate professors nearly always disagreed). Swirling around in my head for years was the notion that a plethora of important connections exists between the physical sciences, social sciences, humanities, business, and the natural environment, and that many of these relationships had not been identified, explored, and emphasized by academia. So, when this pivotal meeting ended, with my mind racing, I gathered myself and chased after the provost until I caught him just as he was leaving the science building. Breathing heavily by this time I said "Sir, I really think you are on to something here. I have dreamed of putting something like this together, but never did I think that such a chance would come." He responded, "Apparently none of your colleagues see much value in this." "Don't worry about that" I said naively, "I know we can make this work. " The next week he called me into his office and asked me to organize and lead this new interdisciplinary program. 
And so my sustainable business odyssey began. I learned that a number of business leaders in West Michigan were already pioneering ways to link profits, people, and the planet. I contacted these forward thinkers and invited them to discuss the design of a new academic program that would provide our graduates with an expertise in conventional business, physical science, and environmental studies, as well as with a new approach to business. Most of these inimitable professionals graciously agreed, and together we set out to develop a program that would provide a training ground for undergraduates in this new approach to business.

Many considerations were a part of the forthcoming academic design process: the interdependencies between man and nature, the key components of thriving human communities, the need to provide a competitive financial advantage for participants, and the intention to pass along a better world to future generations of all species. The challenge was indeed formidable but our group was knowledgeable, passionate, and committed.

These anecdotes are some of the background circumstances behind my involvement in the sustainable business movement. Further, having two daughters and two granddaughters motivates me to work as an educator for positive change for the future. I am sure you have your own personal stories and a rich mixture of reasons for considering all or part of the paradigm shift presented in the following chapters. Nature is filled with rich diversity and countless interrelationships among all members, and the sustainable business revolution is taking shape in a similar fashion. A variety of people in many parts of the world are independently beginning to redesign business and to find remedies for many of the existing core problems of commerce. 


\section{Acknowledgements}

The author thanks the Steelcase foundation for its gracious and generous support of this project, and offers special thanks to former board trustee Peter M. Wege for his many contributions to a healthy and bountiful West Michigan.

The author thanks Aquinas College President C. Edward Balog for his continuous leadership, support, and confidence.

The author thanks student worker Mariel Borgman for her assistance during the completion of this work.

The author thanks his longtime friend Jim for inspiration in the earliest stages of this project.

The author lovingly thanks his wife, Maggie, for her patience and support during the many months of work that spilled into our private time and for her countless hours of editing and advisement. 
This page intentionally left blank 


\section{Contents}

Preface vii

Acknowledgements $\quad$ xvii

1. Houston, We Have a Problem 1

1.1 Our Early Approach to Mounting Problems 2

1.2 Our Problems Continue 4

1.3 Early Visionaries and the Resistance to Change 7

1.4 Do Current Free-Market Mechanisms Help? 8

1.5 An Intelligent Beginning 11

1.6 Are the Results Worth the Effort? 13

2. Selecting a Design Consultant 19

2.1 The Problem with Stewardship 19

2.2 Naturally Our Best Foot Forward 22

2.3 Pernicious Material Processes 24

2.4 Nature's Path of Production 25

2.5 Two Closed-Loops into One 29

2.6 Nature's Energy Path 32

2.7 Following Nature's Energy Path 34

2.8 Other Sun-Powered Opportunities $\quad 35$

2.9 Envision a Sun-Powered Human Society 36

2.10 Cutting Our Nuclear Power Losses 38

2.11 The Advantages of Local Energy Production 39

2.12 Changing Energy Trends 40

2.13 Innovations Solving Multiple Problems 43 
3. The Bull's Eye

3.1 The Triple Top-line

3.2 The Short Post on the Three-Legged Stool 47

3.3 The Nature of the Movement 48

3.4 High Stakes and New Takes 49

3.5 How Do We Begin? 51

3.6 No Silver Bullet 53

3.7 The Better Part of Valor $\quad 54$

3.8 The Toyota Way $\quad 58$

3.9 Approaching the Bull's Eye $\quad 59$

3.10 Intelligent Building Design 61

3.11 Urgent Challenges, Appropriate Remedies 63

3.12 Early Organizational Change 66

3.13 The Score Card $\quad 67$

3.14 A Helping Hand $\quad 70$

3.15 Staff Roles in the Transition 71

4. Businesses Taking Care of Business 77

4.1 United States For-Profit Companies 78

4.2 European For-Profit Companies 94

4.3 Caribbean and South American For-Profit 100 Companies

4.4 Australian For-Profit Companies. 102

4.5 Asian For-Profit Companies 102

4.6 Non-Profit Organizations 106

4.7 Sustainable Business Forums 108

4.8 Other U.S. Non-Profit Organizations 112

4.9 Laying the Foundation 115

5. Greasing the Cognitive Skids 119

5.1 Connected on All Levels 121

5.2 Field-Based Education $\quad 122$

5.3 Re-educate the Educators $\quad 125$

5.4 Obstacles for Education Reform 127

5.5 The Operations Side of Education 130

5.6 An Academic Prototype 131 
5.7 Research and the Movement

5.8 The Interdisciplinary Aspect 137

5.9 The Academic Program and Curricula 138

5.10 Current Undergraduate Programs 139

5.11 Graduate Programs 141

6. Government Finally Gets It Right 145

6.1 Not Repeating Mistakes 146

6.2 Crafting Sustainable Business Policy 148

6.3 Reforming the Corporate Rules 151

6.4 Operational Advances for Government 153

7. Healthy, Beautiful, Diverse, and Durable 159

7.1 Your Home 160

$\begin{array}{ll}7.2 \text { Transportation } & 163\end{array}$

7.3 Your Retail Experience $\quad 164$

$\begin{array}{ll}7.4 \text { Formal Education } & 170\end{array}$

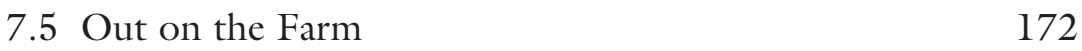

$\begin{array}{ll}7.6 \text { Your Workplace } & 175\end{array}$

8. Falling Off the Log 183

8.1 Recognizing the Threats 183

8.2 Opportunistic or Altruistic 184

8.3 An Aversion to Risk 186

8.4 The Overwhelming Cost 187

8.5 Indecent Exposure 188

8.6 Pretenders and Emasculators $\quad 192$

8.7 Six Essential Characteristics 193

8.8 International Implications 195

8.9 Back to the Front 198

Bibliography 201

$\begin{array}{ll}\text { Index } & 203\end{array}$ 